\title{
Calculation of vehicle delay at signal-controlled intersections with adaptive traffic control algorithm
}

\author{
Roman Andronov ${ }^{1, *}$, and Evgeny Leverents ${ }^{1}$ \\ ${ }^{1}$ Tyumen Industrial University, 625000 Tyumen, Russia
}

\begin{abstract}
By widely introducing information technology tools in the field of traffic control, it is possible to increase the capacity of hubs and reduce vehicle delays. Adaptive traffic light control is one of such tools. Its effectiveness can be assessed through traffic flow simulation. The aim of this study is to create a simulation model of a signal-controlled intersection that can be used to assess the effectiveness of adaptive control in various traffic situations, including the presence or absence of pedestrian traffic through an intersection. The model is based on a numerical experiment conducted using the Monte Carlo method. As a result of the study, vehicle delays, queue length and duration of traffic light cycles are calculated subject to different intensities of incoming traffic flows, and the presence or absence of pedestrian traffic.
\end{abstract}

\section{Introduction}

In recent years, there is a trend towards introduction of information technologies in the field of traffic control in cities with the aim of eliminating congestion and reducing vehicle delays. Transport navigation systems for navigating city streets and automated traffic control systems are becoming more popular; they are synchronized with GPS navigation data; the so-called smart traffic light technology is introduced, etc. [1]. This trend is consistent with the principle of sustainable urban development and should ultimately lead to implementation of the livable city concept [2].

One of acceptable solutions to the traffic congestion problem is the use of automated traffic control system (ATCS). Adaptive traffic light control adjustable to traffic intensity is a particularly attractive solution.

The latest generation of ATCS is developed with regard to data from navigation systems (GPS, Glonass, Galileo) [3, 4], with the priority given to vehicles of emergency services [5]. However, most of current adaptive control systems use data from passage and vehicle presence detectors $[6,7,8]$. Spectrum 2.0, SCOOT and UTOPIA belong to this type of ATCS.

Due to adaptive traffic control vehicle delays at signal-controlled intersections can be reduced by $10-60 \%$ [8]. In order to justify the use of adaptive traffic control at a signalcontrolled intersection, it is necessary to know time of vehicle delays and a value by which

\footnotetext{
* Corresponding author: aroma77777@mail.ru
} 
they will be reduced. Some software products, such as VISSIM and Anylogic, have add-on modules for adaptive traffic control, but software vendors protect methodology and mechanisms behind these modules as a trade secret.

The applicable reference document of the Russian Federation [9] contains recommended uses of adaptive control but this document is over 40 years old and, therefore, does not reflect contemporary realities. Also, the introduction of the road safety audit concept [10] requires assessing the quality of roads and streets in terms of traffic safety. This task is performed in urban conditions by singling out pedestrian traffic as a separate phase with a resulting decrease in the overall traffic capacity of intersections.

The aim of this study is to create a numerical model representing performance of an isolated intersection under adaptive control to obtain reliable average values of traffic light cycle, queue length and vehicle delays in a stationary stochastic flow.

The novelty of the study lies in the model of traffic flow through a signal-controlled intersection with adaptive control. Provided that a traffic situation is simulated multiple times with different initial conditions, this model makes it possible to calculate average values of queue parameters and vehicle delays.

\section{Materials and Methods}

Based on traffic flow patterns, this study proposes a simulation model of traffic flows at an isolated signal-controlled intersection with numerical Monte Carlo simulation [11] and subsequent calculation of vehicle delays and queue parameters. This method has proved itself in simulating both complex systems and traffic flows at micro- and macrolevels [12, 13].

Processes of approaching vehicles to the intersection and leaving it from the stop line at specific intervals are simulated. As a result, there is a queue of cars which should be completely resolved for the next green phase. There is a significant spread of data, including queue parameters, duration of phases and the final value of delays. The essence of the method is to simulate the traffic situation multiple times with the aim of achieving a final average result with required reliability and confidence.

\section{Experiment}

To avoid overloading of the model, a conditional intersection of two-lane one-way streets was selected. Activation of the enabling signal and beginning of movement of vehicles occurred alternately subject to the passage of the entire queue of vehicles on the intersected street and the appearance of a gap in the flow [8] (a 5-second interval during which no vehicle approaches the stop line).

The simulation was performed without regard to pedestrian traffic and with a pedestrian phase. A 20-second pedestrian phase was activated alternately in the final part of the traffic light cycle. These conditions satisfy the performance of the Spectrum 2.0 adaptive light control system.

Approaching vehicles for a short time interval (5 seconds) was emulated on the assumption of a Poisson distribution of intervals. The flow was assumed to be stationary for a one-hour interval. The passage of cars through the stop line in traffic conditions with a stable saturation flow was subject to the normal distribution law. The saturation flow was simulated in "ideal" conditions (absence of slopes, good visibility, summer season, sufficient coefficient of adhesion).

The general nature of the simulation is presented in formulas 1 and 2 . 


$$
x_{i}=F^{-1}\left(x_{a v}, \sigma_{x}, s\right)(1) y_{i}=F^{-1}\left(y_{a v}, \sigma_{y}, K_{h}, r\right)(2)
$$

where $r, s$ are uniformly distributed random numbers in the range of 0 to 1 ;

$x_{a v}, y_{a v}$ are mathematical expectations for the traffic capacity of the stop line at the intersection (lane) and suitable number of vehicles per cycle, respectively, vehicles $/ 5 \mathrm{~s}$; $\sigma_{x}, \sigma_{y}$ are the standard deviations of the traffic capacity of the stop line at the intersection (lane) and suitable number of vehicles per cycle, respectively, vehicles $/ 5 \mathrm{~s}$.

In order to create a virtual model of intersection and carry out a numerical experiment, we used an Excel data systematization tool, which, despite its relative simplicity, offers a large set of mathematical formulas and computation techniques in its latest versions. Another advantage of this application is that it can be conveniently used with statistical models, since the Monte Carlo method is based on statistical modeling, one of types of simulation modeling [14].

Adaptive algorithms were implemented by switching through logical functions and links with given parameters of accumulated and resolving queues.

The methodology given in this study can be implemented in any programming language, including Python.

When the intersection is close to its capacity limit, the time of the traffic light cycle with adaptive control can grow infinitely. Some authors recommend limiting this parameter [8]. In this paper, however, the cycle time was not limited due the principle of comparative simplicity.

\section{Results}

The results of the numerical experiment are shown in Tables 1, 2 and Figures 1, 2. In addition, we compared the results with delay of one vehicle subject to fixed traffic light control. A technique based on the Webster's formula [15] is suitable for this purpose.

In total, the model was simulated 50 times for each traffic situation. This number was selected with the aim of reaching the required confidence level (95\%) and permissible error of mean result (not more than 10\%). The relevance of the obtained data is supported by the general theory of traffic flows and preliminary experiments, in particular those described in [16].

Table 1. Results of the numerical experiment, without regard to the pedestrian phase.

\begin{tabular}{|c|c|c|c|c|c|c|c|c|}
\hline \multirow{2}{*}{$\begin{array}{c}\text { Traffic } \\
\text { intensity } \\
\text { for the } 1 \mathrm{st} \\
\text { street }\end{array}$} & \multirow{2}{*}{$\begin{array}{c}\text { Traffic } \\
\text { intensity } \\
\text { for the } 2 \text { nd } \\
\text { street }\end{array}$} & \multicolumn{3}{|c|}{ Cycle duration, $\mathrm{s}$} & \multicolumn{2}{|c|}{ Delays, s } & \multicolumn{2}{|c|}{$\begin{array}{c}\text { Deviation of average } \\
\text { delay }\end{array}$} \\
\hline & & Min & Max & Average & $\begin{array}{l}\text { Fixed } \\
\text { control }\end{array}$ & $\begin{array}{l}\text { Adaptive } \\
\text { control }\end{array}$ & Absolute & Relative \\
\hline 300 & 300 & 15 & 50 & 31.3 & 19.1 & 11.9 & 7.20 & $38 \%$ \\
\hline 500 & 500 & 20 & 55 & 39.4 & 20.7 & 12.3 & 8.44 & $41 \%$ \\
\hline 1,000 & 500 & 30 & 75 & 49.3 & 24.23 & 13.7 & 10.56 & $44 \%$ \\
\hline 1,000 & 1,000 & 40 & 125 & 78 & 26 & 18.2 & 7.81 & $30 \%$ \\
\hline 1,500 & 500 & 25 & 105 & 67.1 & 19.25 & 16.0 & 3.26 & $17 \%$ \\
\hline 1,200 & 1,200 & 40 & 215 & 128.9 & 29.7 & 25.8 & 3.93 & $13 \%$ \\
\hline 1,400 & 1,000 & 65 & 205 & 116.3 & 30.63 & 24.4 & 6.27 & $20 \%$ \\
\hline
\end{tabular}


Table 2. Results of the numerical experiment, with regard to the pedestrian phase.

\begin{tabular}{|c|c|c|c|c|c|c|c|c|}
\hline $\begin{array}{c}\text { Traffic } \\
\text { intensity } \\
\text { for the 1st } \\
\text { street }\end{array}$ & $\begin{array}{c}\text { Traffic } \\
\text { intensity } \\
\text { for the 2nd } \\
\text { street }\end{array}$ & \multicolumn{3}{|c|}{ Cycle duration, s } & \multicolumn{2}{c|}{ Delays, s } & \multicolumn{2}{c|}{$\begin{array}{c}\text { Deviation of average } \\
\text { delay }\end{array}$} \\
\cline { 5 - 10 } & Min & Max & Average & $\begin{array}{c}\text { Fixed } \\
\text { control }\end{array}$ & $\begin{array}{c}\text { Adaptive } \\
\text { control }\end{array}$ & Absolute & Relative \\
\hline 300 & 300 & 20 & 75 & 57.8 & 27 & 22.4 & 4.60 & $17 \%$ \\
\hline 500 & 500 & 45 & 95 & 74.2 & 29.2 & 24.5 & 4.69 & $16 \%$ \\
\hline 1,000 & 500 & 70 & 130 & 95.4 & 30 & 27.69 & 2.31 & $8 \%$ \\
\hline 1,000 & 1,000 & 95 & 225 & 161.2 & 39.9 & 37.19 & 2.71 & $7 \%$ \\
\hline 1,500 & 500 & 85 & 185 & 134 & 34.4 & 32.87 & 1.53 & $4 \%$ \\
\hline 1,200 & 1,200 & 170 & 370 & 244.9 & 54.3 & 52.97 & 1.33 & $2 \%$ \\
\hline 1,400 & 1,000 & 140 & 315 & 236.9 & 58.8 & 52.0 & 6.80 & $12 \%$ \\
\hline
\end{tabular}

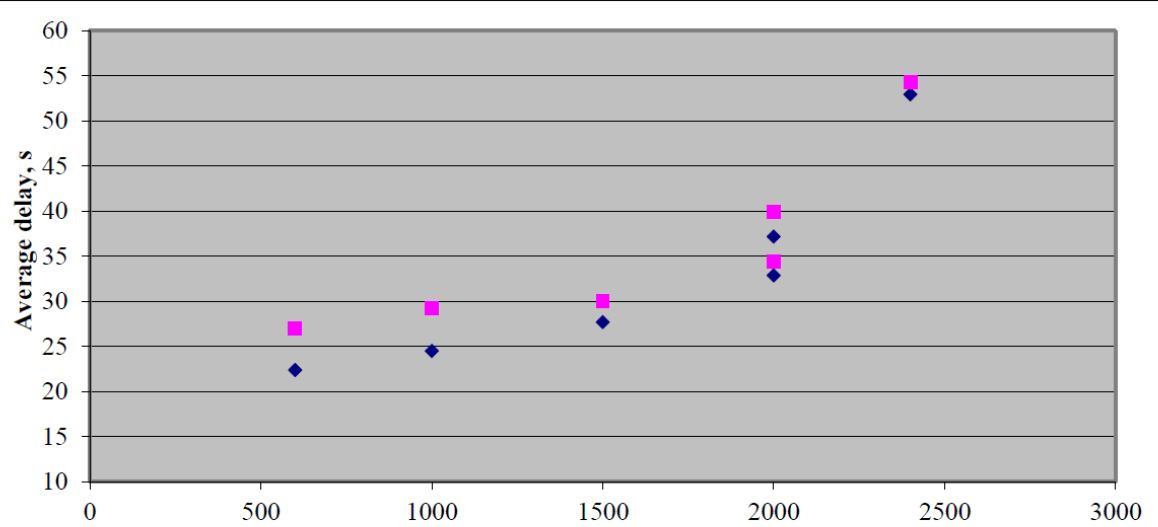

Total traffic intensity for intersected streets, vehicles/h

$\checkmark$ Adaptive control $\quad$ Fixed control

Fig. 1. Average vehicle delay, without regard to the pedestrian phase at the intersection.

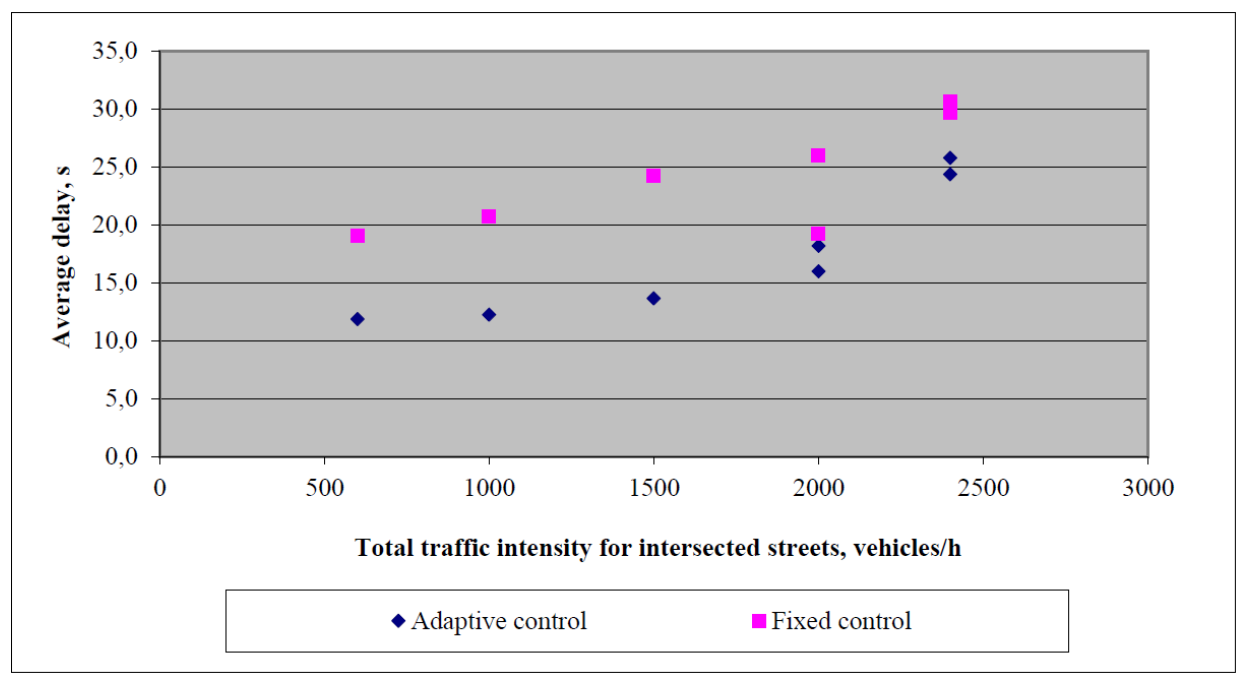

Fig. 2. Average vehicle delay, with regard to the active pedestrian phase at the intersection. 
As can be seen from the tables, adaptive control is very effective for intersections with relatively low load levels (delays decreased by 30-44\%). But it remains significant even at high levels if absolute values of delays and increased traffic intensity are taken into account. The total time loss at the intersection will be significant as well.

In the presence of pedestrian phase, adaptive regulation loses its effectiveness due to many actuations of this phase. Therefore, it is necessary to consider limiting the number of its actuations or using pedestrian-controlled traffic lights, if there is light pedestrian traffic at the intersection.

Based on the developed model, it is possible to simulate a real-life traffic flow throughout the day where a traffic flow is unevenly distributed across the day, and then to check the convergence of results. This model is especially relevant when it comes to combination of adaptive regulation with reorganization of intersections (allocation of lanes for turning, additional phases), which is particularly important in central parts of dense cities where large-scale reconstruction is a challenge.

Further, it is advisable to identify a recommended field of application for adaptive control in the same way as in [9], as related to various types of intersections, traffic situation at them and possible reorganization.

\section{Conclusion}

In this study, the simulation model of a signal-controlled intersection with adaptive control was developed using the Monte Carlo method; final average values of vehicle delays, duration of traffic light cycle and queue length were calculated. This model can be used to simulate the performance of crossings in various traffic situations with or without pedestrian traffic.

It is necessary to determine a recommended field of application for adaptive control as related to various types of intersections and traffic situations at them. In addition, knowing recommended applications of adaptive traffic light control will make it possible to optimize road traffic and to reconstruct road networks in a more purposeful and effective manner.

\section{References}

1. A.K. Debnath, Cities 37, 47-56 (2014)

2. V.R. Vuchic, Transportation for Livable Cities (Territorija budushhego, 2011) (in Russian)

3. V. Astarita, V.P. Giofrè, A.A. Vitale, ASRJETS 19, 1 (2016)

4. A.O. Evdokimov, A.V. Gorohov, D.Ja. Lugov, I.R.J. 5, 55 (2015)

5. S. Djahel, Adaptive traffic management for secure and efficient emergency services in smart cities (PERCOM Workshops, IEEE, 2013)

6. E.A. Petrov, Transportnaja strategija XXI vek [Transport strategy - XXI century] 12 (2011) (in Russian)

7. V. Erisov, V. Trushevski, EEJET 4, 9 (2014)

8. Ju.A. Kremenec, M.P. Pecherskij, M.B. Afanas'ev, Tehnicheskie sredstva organizacii dorozhnogo dvizhenija [Technical facilities for traffic organization] (Akademkniga, 2005) (in Russian)

9. V.M. Polukarov, L.A. Jakushin, Rukovodstvo po proektirovaniju $i$ vnedreniju avtomatizirovannyh sistem upravlenija dorozhnym dvizheniem na baze ASSUD [A Manual on the Design and Implementation of Automated Traffic Control Systems] (MIA USSR, 1981) (in Russian)

10. ODM 218.6.010-2013. Metodicheskie rekomendacii po organizacii audita bezopasnosti dorozhnogo dvizhenija pri proektirovanii i jekspluatacii avtomobil'nyh 
dorog [Methodical recommendations on the organization of road safety audit in the design and operation of highways] (Informavtodor, 2014) (in Russian)

11. N. Metropolis, S. Ulam, JASA 44, 247 (1949)

12. S. Sinha, Dynamics of urban traffic congestion: A kinetic Monte Carlo approach to simulating collective vehicular dynamics (COMSNETS, IEEE, 2016)

13. S. Tsiakmakis, TRR Journals 2572, 66-77 (2016)

14. V.V. Silyanov, Teorija transportnyh potokov v proektirovanii dorog $i$ organizacii dvizhenija [Theory of traffic flows in the design of roads and traffic organization] (Transport, Moscow, 1977)

15. ODM 218.6.003-2011. Metodicheskie rekomendacii po proektirovaniju svetofornyh objektov na avtomobil'nyh dorogah [Methodical recommendations on the design of traffic lights on highways] (Росавтодор, 2013)

16. R.V. Andronov, Modelirovanie ocheredej na reguliruemyh peresechenijah ulichnodorozhnoj seti krupnogo goroda $v$ uslovijah plotnogo transportnogo potoka [Modeling of queues at regulated street intersections in a large city within the dense traffic] (Tyumen, 2007) 